\title{
Nutritional Status of Children Under Five Years in the Work Area of Puskesmas Cipadung
}

\author{
Zidni IIma Nafi'a*, Istiqomah Zakiyah Shodiq, and Lina Handayani \\ Faculty of Public Health, Universitas Ahmad Dahlan, Yogyakarta, Indonesia \\ *corresponding author, e-mail: ilmanafiazidni27@gmail.com
}

Received: 24/08/2021; published: 15/09/2021

\begin{abstract}
Background: Children under five years are in the golden growth and development period; however, an excellent nutritional status must support optimal growth and development. The nutritional status of children under five years needs special attention. An overview of the nutritional status of children in a region is the first step to determine the factors that affect the nutritional status of children under five in that region. Method: This was a descriptive study with a cross-sectional design. Results: The results showed that children under five aged $0-23$ months were $35.47 \%$, while those aged $24-59$ months were $64.53 \%$, boys were $52.95 \%$, and girls were $47.05 \%$. Children under five years with inferior nutritional status (index weight/age) of $2.63 \%$, children with nutritional status of stunting (index for height/age) of $12.57 \%$. Children with a malnutrition status (index weight/height) of $2.41 \%$. Conclusion: The problem of stunting and wasting nutrition is still found in the work area Puskesmas Cipadung. These problems can arise due to poor parenting and lack of nutritious food intake due to parents' low education and income level.
\end{abstract}

Keywords: Nutritional status, Children under five years, Malnutrition

This is an open-access article under the CC-BY-SA license.

\section{Introduction}

As part of the countries in the world, Indonesia also contributes to global development efforts regulated in the Sustainable Development Goals (SDGs). The SDGs consist of 17 goals and 169 development targets expected to answer the underdevelopment of countries worldwide, both in developed and developing countries. The second objective in the SDGs is "Zero Hunger," a health sector where the focus of its activities is the role of the public nutrition sector. The goal of "Zero Hunger" referred to in the SDGs is to end hunger and ensure access to safe, nutritious, and sufficient food for all people, especially the poor and vulnerable, including infants, throughout the year and end all forms of malnutrition, including achieving the 2025 international target for reduction of stunting and wasting in under-five children and addressing the nutritional needs of adolescent girls, pregnant and lactating women, and the elderly.

Infancy is a time of formation and development of humans. This stage is vulnerable because children under five years are susceptible to growth disorders and their dangers. Children under five years are also known as a period golden age, which formed the basics of the ability to sense, think, speech and mental growth intellectually intensive and early moral growth [1]. In the 2015 - 2019 Rencana Pembangunan Jangka Menengah Nasional (RPJMN) or National Medium Term Development Plan in Indonesia, the target to achieve the nutritional status of children under five includes $17 \%$ prevalence of malnourished and underweight children and $28 \%$ prevalence of short and very short Bawah Dua Tahun (Baduta). As for the 2018 Riset Kesehatan Dasar (Riskesdas) or Basic Health Research, malnutrition and malnutrition in Indonesia were $17.7 \%$. The nutritional status of children under five is concise, 
and stunting in Indonesia is $30.8 \%$. The prevalence of underweight and very thin or wasting nutritional status in Indonesia is $10.2 \%$, while children under five with fat nutritional status in Indonesia is $8 \%$. The nutritional status of children under five is of particular concern because, in the 2020-2024 RPJMN, there are significant changes in the prevalence of stunting and wasting, where the prevalence of stunting is $19 \%$ while the prevalence of wasting is $7 \%$. Of course, it takes hard work and intelligent work, and cross-sectoral involvement in achieving the desired targets. The increase in the RPJMN target in Indonesia is not without reason, as it is well known that nutrition problems in children under five, especially stunting and wasting, will have a long-term impact on under-five children who experience this nutritional status. Therefore, monitoring the nutritional status of under-five children on an ongoing basis is essential to detect children with nutritional problems early. Intervention endeavors also carry out quickly so that serious problems do not arise immediately.

Based on the UNICEF framework adapted to Indonesia's conditions, causes of nutritional problems consist of the direct cause, indirect cause, root of the problem, and the subject matter. The direct causes are children's food consumption and infectious diseases that the child may suffer. The cause of malnutrition is not only due to the lack of food but also infectious diseases. Children who eat well but have frequent diarrhea or fever can suffer from malnutrition. As for the indirect causes, food safety within the family, parenting, health care, and environmental health are examples. These factors are strongly associated with the level of education, knowledge, and skills of the family. Parenting can affect the child's food intake and infectious diseases that under-five children may suffer [2].

In early 2020 the Covid-19 pandemics hit the world. Indonesia was inseparable from the pandemic. The Covid-19 pandemic has also affected health services in the community, monitoring the growth and development of under-five children. Based on a report from the Directorate of Public Nutrition, Ministry of Health, Republic Indonesia, wasting and stunting predicted to increase during the Covid-19 pandemic, and only $19.2 \%$ of Puskesmas have been carried out Posyandu activities. This situation will certainly make it challenging to find out the nutritional status of children under five in the community. After the majority of growth and development monitoring activities at Posyandu have stopped in Indonesia due to the Covid19 pandemic, entering the month of August or what is known as Bulan Penimbangan Balita (BPB) or Children Under Five Years Weighing Month, growth and development monitoring activities must still be carried out with procedures adjusting to the conditions of the Covid-19 zone in the area. Usually, BPB in Indonesia is followed by the provision of vitamin A and worm medicine. The weighing month activity in August 2020 is crucial because apart from being a description of the nutritional status of under-five children in general, it is also to know the nutritional status of children during the Covid-19 pandemic. Therefore, the authors wanted to know the prevalence of the nutritional status of under-five children in the working area of the Puskesmas Cipadung, Bandung City in, August 2020.

\section{Method}

This research was descriptive with a survey that aimed to determine the nutritional status of children under five in the working area of the Puskesmas Cipadung, Bandung City. A sample of 2,442 children under five years was monitored growth and development in August 2020 in the working area of Puskesmas Cipadung, namely in Cipadung Village and Palasari Village, Cibiru District, Bandung City. Data processing was done manually and using a computer. The data was collected and displayed in the form of a frequency distribution table and writing.

Monitoring data for children's growth and development was divided into three indicators of nutritional status. The three indicators were the index weight/age (WAZ), height/age (HAZ), and weight/height (WHZ). The body weight/age index describes the relative body weight compared to the child's age. This index was used to assess children underweight or severely underweight but cannot classify children as obese or very obese. It was essential to know that a child with a low weight/age may have growth problems, so it needed to confirm with a weight loss index or body weight/height or BMl/age before intervention. The height/age index describes the length or height growth of a child based on their age. This index can identify short (stunted) or very short (severely stunted) children caused by prolonged malnutrition or frequent illness.

Children classified as tall by age can also identify. Endocrine disorders usually cause children above normal (very high), but this is rare in Indonesia. This weight/body weight index 
or body weight/height describes whether the child's weight is suitable for the growth in length/height. This index can use to identify children who are undernourished (wasted), malnourished (severely wasted), and children who have a risk of being overweight (possible risk of overweight). The condition of malnutrition is usually caused by disease, and lack of nutritional intake has just occurred (acute) or has been occurring for a long time (chronic).

\section{Results and Discussion}

\subsection{Results}

Based on 2,442 children under five, most were boys, with 1,293 boys (52.95\%) and age 24-59 months, amounting to 1,554 children (63.64\%). The result showed that under-five children's nutritional status based on the weight/age index was the most under-fives with average weight nutritional status (79.69\%), based on the height Index by age were normal 2,116 children $(86.65 \%)$, based on a weight-to-height index (WHZ) were 1,773 normal children (72.64\%). More details can be seen in Table 1.

Table 1. Univariate Analysis Result

\begin{tabular}{|c|c|c|c|c|c|c|}
\hline \multirow{2}{*}{ Variable } & \multicolumn{2}{|c|}{ Cipadung Village } & \multicolumn{2}{|c|}{ Palasari Village } & \multicolumn{2}{|c|}{$\begin{array}{c}\text { Puskesmas } \\
\text { Cipadung }\end{array}$} \\
\hline & $\mathbf{n}$ & $\%$ & $\mathbf{n}$ & $\%$ & $\mathrm{n}$ & $\%$ \\
\hline \multicolumn{7}{|l|}{ Gender } \\
\hline Boys & 683 & 51.67 & 610 & 54.46 & 1,293 & 52.95 \\
\hline Girls & 639 & 48.33 & 510 & 45.54 & 1,149 & 47.05 \\
\hline \multicolumn{7}{|l|}{ Age (month) } \\
\hline $0-23$ & 469 & 51.67 & 419 & 54.46 & 888 & 52.95 \\
\hline $24-59$ & 853 & 48.33 & 701 & 45.54 & 1,554 & 63.64 \\
\hline \multicolumn{7}{|l|}{ WAZ } \\
\hline $\begin{array}{l}\text { Severely } \\
\text { Underweight }\end{array}$ & 25 & 1.89 & 39 & 3.48 & 64 & 2.63 \\
\hline Underweight & 126 & 9.54 & 76 & 6.79 & 202 & 8.27 \\
\hline Normal & 1,051 & 79.50 & 895 & 79.91 & 1,946 & 79.69 \\
\hline Risk Over & 120 & 9.07 & 110 & 9.82 & 230 & 9.41 \\
\hline \multicolumn{7}{|l|}{ HAZ } \\
\hline Very short & 46 & 3.48 & 28 & 2.5 & 74 & 3.03 \\
\hline Short & 135 & 10.21 & 98 & 8.75 & 233 & 9.54 \\
\hline Normal & 1,126 & 85.17 & 990 & 88.39 & 2,116 & 86.65 \\
\hline High & 15 & 1.14 & 4 & 0.36 & 19 & 0.78 \\
\hline \multicolumn{7}{|l|}{ WHZ } \\
\hline Poor nutrition & 30 & $2 / 26$ & 29 & 2.58 & 59 & 2.41 \\
\hline Undernutrition & 113 & 8.54 & 69 & 6.16 & 182 & 7.45 \\
\hline Normal & 949 & 71.79 & 824 & 73.58 & 1,773 & 72.64 \\
\hline $\begin{array}{l}\text { Risk of Over } \\
\text { Nutrition }\end{array}$ & 146 & 11.04 & 123 & 10.98 & 269 & 11.00 \\
\hline Over Nutrition & 50 & 3.79 & 53 & 4.74 & 103 & 4.21 \\
\hline Obesity & 34 & 2.58 & 22 & 1.96 & 56 & 2.29 \\
\hline
\end{tabular}

\subsection{Discussion}

Malnutrition is a consequence of consuming dietary nutrients either insufficiently or exclusively by especially children [3]. The children under five period is a critical period for future survival; therefore, health conditions, including the nutritional status of children under five years, need to be considered. Nutrition problems have a broad dimension; if the nutrition consumption in infants is not balanced, it will result in nutritional status problems [4]. Wasting and being underweight reflect poor nutrition, which in children leads to retarded growth [5]. Pandemic conditions that hamper the development of children under five may increase the percentage of children with malnutrition and malnutrition problems.

A mother's level of knowledge can affect the nutritional status of under-five children. Most mothers with good knowledge have under-five children with good nutritional status than mothers with less knowledge [6]. Insufficient knowledge of mothers can impact the attitudes and behavior of mothers in providing food to under-five children, which causes nutritional 
imbalances needed by under-five children so that under-five children have poor nutritional status. The lower the mother's education level, the more children under five years tend to be stunted [7]. According to research, the knowledge in humans depends on the level of education obtained both formally and informally, where the level of knowledge will influence how a person understands knowledge about nutrition and health [8]. Mother knowledge factor can affect the incidence of childhood malnutrition at the Puskesmas Cipadung due to the education level of the female population in the Puskesmas Cipadung working area was mainly at the SD / MI graduation level, which was 5,348 out of the 16,145 total female population.

Family income also affects the nutritional status of children under five years. The level of income also determines the type of food to be served with additional money. The higher the income, the greater the percentage of the income used to buy fruit, vegetables, and various types of food so that income is an essential factor for the quality and quantity of income and nutrition, there is a clear beneficial relationship [9]. Children from the lower-middle class had a greater risk of stunting (OR 2.1, $\mathrm{p}<0.001)$ than those from the upper-middle class. The family's socioeconomic status is known to be associated with children's nutritional status [10]. Family economic factors can impact low purchasing power, in this case, food for the family. If the quality and quantity of food consumption cannot be adequately fulfilled, it can lead to malnutrition in children under five years[11]. Most of the population in the working area of the Puskesmas Cipadung do not have settled jobs or are unemployed. The condition of irregular livelihoods affects the income that is not fixed and tends to be low income, affecting food purchasing power in the family structure.

Research shows a relationship between parenting styles and nutritional status in children under five [12]. Bad parenting impacts the nutritional status of children under five, which is not good. Based upon the low level of mother's education and irregular livelihoods, it can affect the poor parenting style of mothers for their children so that it impacts the poor nutritional status of children under five in a family. There is a significant relationship between Perilaku Hidup Bersih dan Sehat (PHBS) and nutritional status or Clean and Healthy Living Behavior. Children under five years with undernourished status are affected by environmental-based infectious diseases, which are still one of the causes of death in Indonesia [13]. Bad PHBS is followed by the poor nutritional status of children under five years. The condition of PHBS in the working area of the Puskesmas Cipadung, some indicators were still low; including the condition of the family latrine, the condition of the family toilet that met the requirements in the working area of the Puskesmas Cipadung was $48 \%$ while the minimum target achievement was $75 \%$. The low condition of family latrines was because households still did not have a septic tank and defecate in the open area. This condition can affect the nutritional status of children under five who live in the area and those who have inadequate latrines.

Table 1 shows that the nutritional status of children under five years is based on the height index according to age; most respondents have nutritional status with normal height $(86.65 \%)$, then the nutritional status of respondents with very short and stunted height $(12.57 \%)$. Stunting is a condition of malnutrition-related to the inadequacy of nutrients in the past, so that it is a chronic nutritional problem. Stunting is measured as nutritional status by considering height or length of the body, age, and sex of children under five years. The habit of not measuring the height or length of the under-five children's bodies in the community causes the incidence of stunting to be challenging to realize [14].

Of 162 million stunting under-five children, $36 \%$ live in Africa, while $56 \%$ are in Asia. Poverty, the absence of exclusive breastfeeding, maternal factors such as poor nutrition during pregnancy, inappropriate weight gain, poor consumption of vitamin supplements, disease, environmental factors, and socioeconomic or household factors all affect the nutritional status of children so that the government of developing countries and the global community must work together to eliminate these factors [3].

The habit of not measuring the height or length of the under-five children's bodies in the community causes the incidence of stunting to be challenging to realize [14]. Short children occur due to a lack of nutritional intake received by the fetus or baby. Malnutrition that occurs since the baby is in the womb until the early days of the child's birth and continues until the child is two years old can cause short under-five children [15].

Some of the factors that influence the incidence of stunting in under-five children include babies born with LBW (Low Birth Weight), exclusive breastfeeding for their babies, nutritional 
status of mothers during pregnancy, and mother's education related to their babies' knowledge of under-five children care [16]. Under-five children with birth weight less than 2,500 grams risk experiencing stunting by 3.82 times. The impact of babies with low birth will last from generation to generation; children with LBW will have fewer anthropometric measurements in their development [17]. The continued impact of low birth weight (LBW) can be in the form of failure to thrive, and if a baby is born with LBW, it should be anticipated that it will be challenging to catch up with average early growth and may cause the child to become stunted as one of the risks [18].

Supplementary feeding that does not focus on the frequency, texture, timing of feeding, and diversity can cause stunting in under-five children. For this reason, as prevention and treatment of stunting, additional food to be given must be able to replace the reduced function of breast milk and according to the nutritional needs of children by taking into account the frequency, texture, and timing of feeding, as well as the diversity of complementary foods [19].

A mother's nutritional status during pregnancy that is good has a greater chance of giving birth to a healthy baby. The nutritional status of mothers during pregnancy who experience Kurang Energi Kronik (KEK) or Chronic Energy Deficiency has a 2.2 times greater risk of stunting under five than the nutritional status of mothers during pregnancy who have normal Lingkar Lengang Atas (LILA) [20]. Perception error and shared knowledge of mothers will undoubtedly impact mother behavior, especially health behavior and child feeding behavior. The incidence of stunting in under-five children is related to nutritional intake in under-five children. The intake of nutrients eaten by under-five children daily depends on the mother so that the mother has an essential role in changing nutritional input for under-five children. Therefore, efforts to improve stunting can be made by increasing knowledge to improve feeding behavior in children. One of the efforts to increase knowledge to change the feeding behavior of children is nutritional counseling [21]. In addition, children of short mothers $(<145$ $\mathrm{cm}$ ) have about twice the risk of experiencing stunting. This notion is supported by research that confirms a solid intergenerational link between the short stature of mothers and stunted, thin children in Bangladesh [22].

Table 1 shows that the nutritional status of under-five children based on weight index according to body height; most respondents have normal nutritional status $(72.64 \%)$, followed by the nutritional status of children under five years with a risk of overnutrition (11\%) and nutritional status of children under five years with less nutrition (7.45\%).

Physical activity of children under five years and parenting patterns contribute to the occurrence of obesity in children. Children with less active physical activity have a 7.66 times greater risk of experiencing excess nutrition. Unsupportive parenting will have a risk of 6.16 times greater in children experiencing excess nutrition [23]. One of the factors that influence nutritional status is the frequency of giving milk. Formula feeding 15 to 24 times per day is associated with increased overnutrition [24].

Consumption of large amounts of formula milk as an infant may lead to a tendency for children to continue consuming milk until they are under-five children. If milk is still consumed in large quantities and is not accompanied by energy expenditure balanced with intake, there will be a build-up of energy, leading to obesity in under-five children. Under-five children who consume large amounts of formula milk as infants tend to have excess energy intake [25]. It is petrified that overnutrition that is not controlled in children will continue until children, adolescents, and adults. This condition is undoubtedly dangerous because later it can become overweight or obese, which can be the basis of diseases, primarily degenerative diseases.

Wasting is a condition of acute malnutrition in children under five years. The body weight for height (WHZ) is an anthropometric index that indicates wasting. This indicator illustrates the acute nature of nutritional problems resulting from a situation that lasts a short time. Wasting is directly caused due to inadequate nutritional intake and infectious diseases in children, while indirectly, it can be influenced by socioeconomic factors, parenting, food availability, and cultural factors. Wasting can have an impact on reducing children's exploration power. In the long term, children who experience loss can also decrease intelligence, productivity, and quality of human resources [26].

The baby's need for nutrition vastly affects the nutritional status of the baby: 
this is proven by the results of research that, on average, babies experience poor nutritional status is more significant than good nutritional status.

This might happen due to the lack of nutritional intake and complementary foods for breastfeeding given by the mother,

which is caused by the lack of information obtained by the mother about the importance of complementary feeding and the business of the mother at work so that there is not enough time for mothers to take care of their children [27].

Parents' knowledge about nutrition is very influential on behavior and attitudes in choosing food for their children. The good nutritional status will determine the high percentage of nutritional status nationally. Ignorance about foods with good nutrition will lead to choosing the wrong food and low nutrition contained in these foods and will cause the child's nutritional status to be poor or lacking [28]. Children with good nutritional status must maintain their food intake and nutritional content in it. So that the child's nutritional status is controlled and the process of growth and development is good [29]. The cause of malnutrition is the consumption and the overall feeding pattern of children under five, which is less or insufficient for their needs. The composition of dishes that are not balanced or less diverse (quality) is also an indirect contributing factor that can influence the parents' economic, cultural, and knowledge level at the same time [30].

\section{Conclusion}

Based on the research results, the nutritional status of children under five based on weight/age, height/age, and weight/height were normal. It seems that the problem of multiple nutrition is also starting to emerge in regions in Indonesia, as indicated by a significant number of children at risk of overnutrition and children with overnutrition. Overall, the number of children under five years who experience nutritional problems cannot be said to be minor; these problems can arise due to poor parenting and lack of nutritious food intake due to low levels of education and parents' income so that specific and comprehensive education. Information, communication, and efforts are needed to be accepted by all parents of children under five years with different backgrounds and the need for particular interventions such as the provision of foods high in nutrients in cases of underweight children.

\section{References}

1. Wiedeman, A. M., Chau, C., Grunau, R. E., McCarthy, D., Yurko-Mauro, K., Dyer, R. A., Innis, S. M., \& Devlin, A. M. (2018). Plasma Betaine Is Positively Associated with Developmental Outcomes in Healthy Toddlers at Age 2 Years Who Are Not Meeting the Recommended Adequate Intake for Dietary Choline. The Journal of nutrition, 148(8), 1309-1314. https://doi.org/10.1093/jn/nxy108

2. Merita M, Sari MT, Hesty H. The Positive Deviance of Feeding Practices and Carring With Nutritional Status of Toddler Among Poor Families. J Kesehat Masy. 2017;13[1]:106-12. DOI: https://doi.org/10.15294/kemas.v13i1.7919

3. Kalu RE, Etim KD. Factors Associated with Malnutrition Among Underfive Children in Developing Countries: A Review. Glob J Pure Appl Sci. 2018;24[1]:69. DOI: https://doi.org/10.4314/gjpas.v24i1.8

4. Marniati, Putri ES, Sriwahyuni S, Khairunnas, Duana M. Knowledge Study, Income Level and Socio-Culture of the Nutritional Status of Toddler. J Nutr Sci. 2020;1[2]:38-44. DOI: https://doi.org/10.35308/jns.v1i2.2770

5. Akombi BJ, Agho KE, Merom D, Hall JJ, Renzaho AM. Multilevel Analysis of Factors Associated with Wasting and Underweight Among Children Under-Five Years in Nigeria. Nutrients. 2017;9[1]. DOI: https://doi.org/10.3390/nu9010044

6. Chien, T. Y., Chien, Y. W., Chang, J. S., \& Chen, Y. C. (2018). Influence of Mothers' Nutrition Knowledge and Attitudes on Their Purchase Intention for Infant Cereal with No Added Sugar Claim. Nutrients, 10(4), 435. https://doi.org/10.3390/nu10040435

7. Kusrini I, Laksono AD. Regional Disparities of Stunted Toddler in Indonesia. Indian J Forensic Med Toxicol. 2020;14[3]:1916-20. DOI: https://doi.org/10.31227/osf.io/6zqdc

8. Alhamid SA, Carolin BT, Lubis R. Studi Mengenai Status Gizi Balita. J Kebidanan Malahayati. 2021;7[1]:131-8. DOI: https://doi.org/10.33024/jkm.v7i1.3068 
9. Lumeng, J. C., Kaciroti, N., Retzloff, L., Rosenblum, K., \& Miller, A. L. (2017). Longitudinal Associations Between Maternal Feeding and Overweight in Low-Income Toddlers. Appetite, 113, 23-29. https://doi.org/10.1016/j.appet.2017.02.016

10. Syihab SF, Stephani MR, Kumalasari I, Suherman A. Socioeconomic Status in Relation to Stunting and Motor Skill Develpoment of Toddlers in Urban and Rural Areas. J Kesehat Masy. 2021;16[3]:340-7. DOI: https://doi.org/10.15294/kemas.v16i3.24382

11. Sudiyah, Rosida L. The Characteristics of Undernutrition in Toddlers. Advannces Heal Sci Res. 2021;34:212-5. DOI: https://doi.org/10.2991/ahsr.k.210127.047

12. Handayani R. Factors Related to Nutritional Status in Children Under Five. J Endur. 2017;2[2]:217-24. DOI: https://doi.org/10.3889/oamjms.2020.3666

13. Kitzinger, J., \& Kitzinger, C. (2018). Deaths After Feeding-Tube Withdrawal From Patients in Vegetative and Minimally Conscious States: A Qualitative Study of Family Experience. Palliative medicine, 32(7), https://doi.org/10.1177/0269216318766430

14. Kwami, C. S., Godfrey, S., Gavilan, H., Lakhanpaul, M., \& Parikh, P. (2019). Water, Sanitation, and Hygiene: Linkages with Stunting in Rural Ethiopia. International journal of environmental research and public health, 16(20), 3793. https://doi.org/10.3390/ijerph16203793

15. Muliyana, Nuraeni, Suriana, Ahmad, M., Syarif, S., As'ad, S., Arifuddin, S., \& Usman, A. N. (2020). Midwives' Perceptions About the Ease of Sisfor_Bidanku Application For Toddler Anthropometric-Based Growth and Development. Enfermeria clinica, 30 Suppl 4, 539-543. https://doi.org/10.1016/j.enfcli.2019.10.134

16. Rakotomanana, H., Gates, G. E., Hildebrand, D., \& Stoecker, B. J. (2017). Determinants of Stunting in Children Under 5 years in Madagascar. Maternal \& child nutrition, 13(4), e12409. https://doi.org/10.1111/mcn.12409

17. Wali, N., Agho, K. E., \& Renzaho, A. (2020). Factors Associated with Stunting among Children under 5 Years in Five South Asian Countries (2014-2018): Analysis of Demographic Health

https://doi.org/10.3390/nu12123875

18. Dewi, N. U., \& Mahmudiono, T. (2021). Effectiveness of Food Fortification in Improving Nutritional Status of Mothers and Children in Indonesia. International journal of environmental research and public health, 18(4), 2133. https://doi.org/10.3390/ijerph18042133

19. Dermyshi, E., Wang, Y., Yan, C., Hong, W., Qiu, G., Gong, X., \& Zhang, T. (2017). The "Golden Age" of Probiotics: A Systematic Review and Meta-Analysis of Randomized and Observational Studies in Preterm Infants. Neonatology, 112(1), 9-23. https://doi.org/10.1159/000454668

20. Yang, L., Li, M., Liu, X., Wu, M., Zhang, J., Zhao, L., Ding, G., \& Yang, X. (2020). Evaluation of lodine Nutritional Status Among Pregnant Women in China. Thyroid : official journal of the American Thyroid Association, 30(3), 443-450. https://doi.org/10.1089/thy.2019.0001

21. Angeles-Agdeppa, I., Monville-Oro, E., Gonsalves, J. F., \& Capanzana, M. V. (2019). Integrated School Based Nutrition Programme Improved the Knowledge of Mother and Schoolchildren. Maternal \& child nutrition, 15 Suppl 3(Suppl 3), e12794. https://doi.org/10.1111/mcn.12794

22. Khatun W, Rasheed S, Alam A, Huda TM, Dibley MJ. Assessing the Intergenerational Linkage Between Short Maternal Stature and Under-Five Stunting and Wasting in Bangladesh. Nutrients. 2019;11[8]:1-15. DOI: https://doi.org/10.3390/nu11081818

23. Hutchens, A., \& Lee, R. E. (2018). Parenting Practices and Children's Physical Activity: An Integrative Review. The Journal of school nursing : the official publication of the National Association of School Nurses, 34(1), 68-85. https://doi.org/10.1177/1059840517714852

24. Katongole, C. B., \& Yan, T. (2020). Effect of Varying Dietary Crude Protein Level on Feed Intake, Nutrient Digestibility, Milk Production, and Nitrogen Use Efficiency by Lactating Holstein-Friesian Cows. Animals : an open access journal from MDPI, 10(12), 2439. https://doi.org/10.3390/ani10122439

25. Patro-Gołąb, B., Zalewski, B. M., Kołodziej, M., Kouwenhoven, S., Poston, L., Godfrey, K. M., Koletzko, B., van Goudoever, J. B., \& Szajewska, H. (2016). Nutritional Interventions 
or Exposures in Infants and Children Aged Up to 3 years and their Effects on Subsequent Risk of Overweight, Obesity and Body Fat: A Systematic Review of Systematic Reviews. Journal of the International Association for the Study of Obesity, 17(12), 12451257. https://doi.org/10.1111/obr.12476

26. Blondin, J. H., \& LoGiudice, J. A. (2018). Pregnant Women's Knowledge and Awareness Of Nutrition. Applied nursing research : ANR, 39, 167-174. https://doi.org/10.1016/j.apnr.2017.11.020

27. Demir, G., Yardimcı, H., Özçelik, A. Ö., \& Çakıroğlu, F. P. (2020). Compliance of Mothers' Breastfeeding and Complementary Feeding Practices with WHO Recommendations in Turkey. Nutrition Research and Practice, 14(6), 654-666. https://doi.org/10.4162/nrp.2020.14.6.654

28. Fadare, O., Amare, M., Mavrotas, G., Akerele, D., \& Ogunniyi, A. (2019). Mother's Nutrition-Related Knowledge and Child Nutrition Outcomes: Empirical Evidence From Nigeria. PloS one, 14(2), e0212775. https://doi.org/10.1371/journal.pone.0212775

29. Suminar E, Wibowo AR. The Correlation Between Infection Diseases History and Nutritional Status in Toddler. Fundam Manag Nurs J. 2021;4[1]:18-22. DOI: https://doi.org/10.20473/fmnj.v4i1.21587

30. Sirkka, O., Hof, M. H., Vrijkotte, T., Abrahamse-Berkeveld, M., Halberstadt, J., Seidell, J. C., \& Olthof, M. R. (2021). Feeding Patterns and BMI Trajectories During Infancy: A MultiEthnic, Prospective Birth Cohort. BMC pediatrics, 21(1), 34. https://doi.org/10.1186/s12887-020-02456-4 